\title{
Toques do griô: a musicalidade sensível de Heloísa Pires de Lima e Leila Leite Hernandez
}

José Nicolau Gregorin Filho

Universidade de São Paulo (São Paulo, Brasil)

ogo após a assinatura da Lei 11.645, que alterou a Lei 10.639, ambas preconizando o ensino de história e cultura africana e afro-brasileira em estabelecimentos de ensino fundamental, uma dezena de títulos sobre África tomou conta do mercado editorial para crianças e jovens.

O objetivo das editoras com esses lançamentos, grande parte deles pertencentes à chamada literatura infantil e juvenil era atender aos pontos que as leis preconizavam e, certamente, competir com outros títulos também produzidos em sua grande maioria para suprir a demanda sobre a temática, até então quase que inexistente dada à tradição educacional do Brasil, concebida que foi, baseada numa visão eurocêntrica.

A maioria dessas obras, no entanto, trouxe uma infinidade de imagens sobre a África: seus costumes e histórias de seus povos marcados pelos estereótipos, muitas vezes tendendo ao preconceito.

Por meio de lendas, mitos ou histórias diversas, essa grande quantidade de obras destinadas apenas para atender, como se mencionou, à emergência de um nicho mercadológico, não era fruto de pesquisa sistematizada sobre a questão e, em seus textos, traziam em novas roupagens imagens esgarçadas dos povos africanos, imagens essas já transformadas em senso comum.

Dentre essa série de obras que tratam de africanidade, tema fundamental para que o povo brasileiro (re)conheça parte de sua origem multicultural, o livro Toques do Griô, de Heloísa Pires de Lima e Leila Leite Hernandez, com ilustrações de Kaneaki Tada, destaca-se por vários motivos; motivos esses que serão expostos a seguir, ainda que de maneira breve.

Primeiramente, as autoras são profissionais de educação de grande destaque no cenário dos estudos africanos. Ou seja, o livro é resultado de exausti- 
vas pesquisas sobre o tema e fruto de uma experiência profissional que ecoa em várias instâncias da sociedade e da vida cotidiana das professoras/autoras; quer pela sua atuação em espaços universitários como docentes e palestrantes, quer pelo envolvimento participativo na divulgação da cultura africana. Kaneaki Tada, seu ilustrador, artista plástico com larga experiência no cenário da publicidade, conseguiu trazer para a linguagem visual toda a expressividade encontrada no texto verbal produzido por Lima e Hernandez.

O livro começa a atrair a atenção do seu leitor a partir do seguinte provérbio malinqué, colocado á guisa de epígrafe: Quem fala, semeia. Quem escuta, colhe.

É exatamente essa a postura de seu leitor, um indivíduo que passa a colher de maneira prazerosa todos os ensinamentos contidos em vinte e um capítulos, metáfora que remete ao mesmo número de cordas da kora, a harpa do noroeste africano. Essa referência à musicalidade e aos instrumentos que acompanham os griôs faz-se sentir por toda a organização dos capítulos e também por meio da estrutura textual.

Nesses vinte e um capítulos, é narrada uma importante epopeia em louvor a Sundiata Keita, fundador do império Mali.

A narrativa apresentada em Toques do griô não segue os padrões de uma linearidade didatizada tão comum em livros de literatura para crianças e jovens e construída apenas para remeter a um conteúdo escolar. Nessa obra, podem ser conhecidos importantes elementos culturais de parte da África, tais como o griô, as griotes e uma gama de relações sociais e de trocas no interior da cultura, com outras culturas e com o meio ambiente.

As ilustrações de Tada, por sua vez, primam por não reproduzir lugares comuns quando o tema a ser semiotizado para a linguagem visual é a África. Publicitário e artista plástico experiente, na sua carreira teve a oportunidade de trabalhar com diversas técnicas, experiência que contribuiu sobremaneira para a construção de traços e cores capazes de mostrar a cultura africana de maneira diferenciada e criativa.

Além de o livro trazer ao seu leitor a textualidade ficcional sobre parte da cultura e das histórias africanas, seu leitor pode encontrar um capítulo intitulado "de palavra em palavra", onde se encontram informações acerca da história do Mali, de sua geografia e das tradições que ali se construíram e se espalharam.

Nessa parte final da obra, há outras formas de diálogo com o leitor para que se estabeleça um contraponto teórico e histórico para delinear de maneira 
sistematizada o conhecimento do meio ficcionalizado na obra literária. Por meio de fotos, gráficos e ilustrações, as imagens de alguns setores de África são apresentadas de maneira a enriquecer e acrescentar informações à literariedade que se construiu na parte primeira.

Voltando à questão proposta no início - o atendimento às leis que tratam da obrigatoriedade da inserção de elementos culturais africanos e afro-brasileiros nos currículos da educação básica - é necessário que se escolham obras de valor estético, como Toques do griô, de cujas páginas podem surgir questões interessantes para essa proposta de convivência multicultural na sociedade e na escola.

\section{Referências bibliográficas}

GREGORIN FILHO, José Nicolau. Literatura infantil: múltiplas linguagens na formação de leitores. São Paulo: Melhoramentos, 2009.

Projeto de leitura: Toques do Griô. São Paulo: Melhoramentos, 2010.

LIMA, Heloísa Pires e HERMANDEZ, Leila Leite. Toques do griô. Ilustrações de Kaneaki Tada. São Paulo: Melhoramentos, 2010.

Recebido em 08 de setembro e aprovado em 10 de outubro de 2010. 